Dejan Ž. Đorđević ${ }^{1}$

University of Niš, Faculty of Economics

SCIENTIFIC REVIEW ARTICLE

Marko Janković ${ }^{2}$

doi:10.5937/ekonomika1503099D

International business school Botevgrad, Bulgaria

Received: August 2, 2015

Accepted: September 3, 2015

\title{
MODERN DISTRIBUTION AND DEVELOPMENT OF HOTEL INDUSTRY IN THE WORLD
}

\begin{abstract}
Global changes in the economy and society, which started in the last decades of the $X X$ century, affected the changes in the hotel industry. These hotel industry changes are in a certain way more distinct than changes in other industries. As the main tourist activity, hotel industry displays all current changes in the tourism industry in the best way. The permanent growth of global tourism directly affects the fast development and dispersion of the hotel industry. The increased demand for hotel services and global economic development influenced changes in the hotel industry and creation of hotel chains on the global level. These hotel chains occupy a large percentage of the world hotel capacities and possess great financial power. One of their fundamental values is reflected in the fact that the inclusion of small hotels into their systems includes a whole range of supporting companies, thus improving the economy at the local level.
\end{abstract}

Key words: Hotel industry, globalization, tourism, development, hotel chains

JEL classification: $L 8$

\section{САВРЕМЕНИ РАЗМЕШТАЈ И РАЗВОЈ ХОТЕЛСКЕ ИНДУСТРИЈЕ У СВЕТУ}

\begin{abstract}
Апстракт
Глобалне промене у привреди и друштву, започете последюих деценија XX века, утицале су и на измене пословаьа у хотелијерству. Ове промене су у извесном смислу изразитије него у другим привредним гранама. Као основна туристичка делатност, хотелијерство најбоље приказује све актуелне промене у туризму. Перманентни раст светске туристичке привреде непосредно утиче и на убрзани развој и дисперзију хотелске индустрије. Повећана тражна за хотелским услугама и општи привредни развој, утицали су на измене у хотелском пословағу и стварању хотелских ланаца, на глобалном нивоу. Ови хотелски ланцุи поседују велики проценат укупних хотелских капацитета, располажу великом финансијском моћи, а једна од нихових основних вредности огледа се и у чињеници да укључивањем мањих хотела у своје системе, укључују и читав низ пратећих предузећа, чиме унапређују привреду на локалном нивоу.
\end{abstract}

Кључне речи: Хотелијерство, глобализација, туризам, развој, хотелски ланции

\footnotetext{
1 dejan.djordjevic@eknfak.ni.ac.rs, ekngeo@gmail.com

2 marko.jankovic@nisparking.rs
} 


\section{Introduction}

The hotel industry is an economic activity within the hospitality industry, which combines spatial and functional accommodation services with the services of nutrition, including related services. It is often said that the hotel industry is a representative catering activity because it is specific for its spatial, technical and technological, organizational and personnel capabilities, which allows achieving full catering service of accommodation, food and beverage within one unit. The basic unit of hotel are hotels, as the best known and most widely spread facilities for providing accommodation, with particularly high quality of accommodation services, personnel and space decoration as well as meeting the demands of modern travelers.

In order to single out the hotel as a special kind of hospitality facility for accommodation and differentiate it from other objects which provide the same type of service, the International Association of hotel owners in 1926 decided on the minimum common characteristics of each object which is likely to be called hotel. These common features refer to: organization and management in the function of high-quality accommodation services, accommodation and food as main activities, architecture, interior and exterior decoration, particular sanitary and hygienic safety and fire protection, room decoration, with the existence of an appropriate number of common areas and sanitary facilities outside commercial rooms, adequate room area and furnishing, clerical and technical staff, kitchen blocks equipped according to modern technical and sanitary standards and so on (Bardi, 2011).

\section{Historical development of hotel industry}

The history of the founders of the hotel industry shows that some of the most influential people in the field of hotel industry such as the Statler, Hilton, Marriott and Wilson introduced innovations in hotels, shaped and laid the foundations of the modern hotel industry.

Ellsworth Statler developed a hotel chain "Stalters", starting with the hotel in Buffalo in New York State in the United States. Conrad Hilton became a successful hotelier after the Second World War when he bought several farms in Texas during the expansion of the oil industry in the region. By purchasing the "Stalters" chain in 1954, Hilton created the first great modern American hotel chain - a hotel group that monitors standardized operating procedures, marketing, reservations, quality of service, food and beverages, technical maintenance and accounting. Hilton Hotels today include "Hilton Garden" and "Hampton", "Embassy" apartments, "Red Line" hotels and inns, "Harrison" conference centre and so on.

Cesar Ritz was a hotelier in the Grand National Hotel Lucerne, Switzerland. Thanks to his leadership skills, the hotel became one of the most popular in Europe, and Cesar Ritz became one of the most respected hoteliers. William Waldorf Astor opened thirteen-storey "Waldorf Hotel" on Fifth Avenue in New York in 1893. This hotel was the realization of his vision of the hospitality industry in New York that would complement his rich friends, by combining the grandeur of European palaces with the warmth and 
comfort of private apartments. Four years later, Waldorf hotel joined seventeen-storey hotel "Astoria", which was built in the vicinity by Waldorf's cousin John Jacob Astor $\mathrm{IV}$, as well as a corridor to connect the two hotels. These hotels became known as the "Waldorf - Astoria" (Bardi, 2011).

Kemons Wilson founded the hotel chain "Holiday Inn" in the early 1950s, in Memphis in the United States. His idea was to build a chain of hotels for families travelling, and later expanded its offer on business travellers. John Willard Marriott founded the hotel chain "Marriott International" in 1957, near Washington. Ernest Henderson and Robert Moore founded the hotel chain "Sheraton" in 1937 in Massachusetts.

Innovations in the hotel industry happened constantly, all for the purpose of attracting more visitors and keeping up with the competition. The idea of a central open space, the atrium, was revolutionary, because all the rooms, from all the floors, could have a view of the lobby on the ground floor. This concept in hotel architecture was first implemented in 1967 at the "Hyatt Regency" in Atlanta, based on the idea of the architect John Portman (www.portmanusa.com). With such innovations, hotels were not only just places to rest, but the capital of entertainment, leisure and events.

In the early 1980s, big hotel chains adopted the concept of selective service, which was faced towards serving business travellers and travellers on a budget. "Hampton Inn" revolutionized the hotel industry as the first brand to promote the selective service, in hotels with comfortable rooms, but with reduced services characteristic of the hotels at that period (restaurants, lounges, meeting rooms and lobby), which led to cost savings for guests in the form of lower prices.

The development of technology has played a major role in the development of products and services offered to guests. Starting from the central heating system, lifts and electric lighting, which first appeared in hotels at the end of the nineteenth century, over the room telephone and radio, air conditioning, television, computers, to the most modern offer of the most advanced technologies such as wireless and IT infrastructure in rooms.

\section{Contemporary trends in hotel chain business in the world}

Hotel industry, as well as tourism in general, from its beginnings until today, has never been more dynamic. Modern technologies, smart phones, social networks, the Internet, the availability of large quantities of information everywhere and at all times, have influenced numerous changes in the hotel business in recent years and this trend is continuing rapidly. In addition to the progress of technology and its direct impact on the hotel business, there is their indirect impact on the hotel business over tourists, the users of hotel services that are changing their habits and have new needs.

In the modern hotel business we should first of all mention the way of branding a hotel, which can be of national and international character. In the strategy of the international hotel branding, the emphasis is primarily placed on the choice of a good hotel location in foreign countries, and the foreign, not domestic clientele. Also, the accent is not on a particular country through the construction of a large number of hotels, but on the expansion of the hotel network in as many countries as possible. Branding of international hotels is performed almost exclusively by large hotel chains through the construction of high-class hotels. 
Branding national hotel chains is mainly based on the construction of hotels of medium and low categories, with the emphasis on the domestic market of the country where the hotel is located. Although it seems that operating national hotel chains is simpler, its business strategy requires a far better understanding of economics and the business of each of the countries where the chain has a hotel (Čačić, 1998).

Depending on the mode of operation and organization, hotel chains are divided into three types: corporate chains, management companies and voluntary chains (consortia) (Čačić, 2010).

Corporate chains are identified by a strong, defined and recognizable trademark. They are recognized in the market in terms of quality, price, service and other features characteristic of a particular hotel chain. The main objective of corporate chains is greater diversification and more successful positioning in the market. By creating numerous brands within the hotel chain, corporate chains achieve high market coverage.

Management companies specialize in the management of hotel chains, brands and independent hotels. These companies do not manage hotels "on the side", but usually have shares in the hotels they manage. Management companies usually retain the name and seat in the founding countries even after their sale to other companies. This type of hotel chains has the greatest tendency toward global business and often overlaps with the business systems of corporate chains (Table 1.).

Table 1. The largest management companies in the world in 2013.

\begin{tabular}{|c|l|c|r|}
\hline No. & \multicolumn{1}{|c|}{ Hotel chain } & Country & $\begin{array}{c}\text { Hotels } \\
\text { managed }\end{array}$ \\
\hline 1. & Home Inns \& Hotels Management & China & 1308 \\
\hline 2. & Plateno Hotels Group & China & 1217 \\
\hline 3. & Marriott International & USA & 1018 \\
\hline 4. & Accor & France & 787 \\
\hline 5. & IHG & United Kingdom & 689 \\
\hline 6. & China Lodging Group & China & 565 \\
\hline 7. & Starwood Hotels \& Resorts Worldwide & USA & 563 \\
\hline 8. & Westmont Hospitality Group & USA & 515 \\
\hline 9. & Hilton Worldwide & USA & 498 \\
\hline 10. & Shanghai Jin Jiang International Hotel Group Co. & China & 480 \\
\hline
\end{tabular}

Source: www.hotelsmag.com

Voluntary chains or consortia provide marketing and reservation services for independent hotels and corporate chains, mainly for those of national character. Common reservation systems are created, without the presence of a hotel chain in a particular market. Hotels involved in consortia retain ownership, but are required to accept the standards of marketing companies, to train employees and so on. When a hotel reaches a certain level of business, there might be a change in ownership (Table 2.). 
Table 2. The largest consortia in the world in 2013.

\begin{tabular}{|c|l|c|r|}
\hline No. & \multicolumn{1}{|c|}{ Hotel chain } & Country & $\begin{array}{c}\text { No. of } \\
\text { rooms }\end{array}$ \\
\hline 1. & Hotusa Hotels & Spain & 235,000 \\
\hline 2. & Best Eurasian Hotels & Russia & 183,200 \\
\hline 3. & Preferred Hotel Group & USA & 173,966 \\
\hline 4. & Associated Luxury Hotels International & USA & 119,644 \\
\hline 5. & Worldhotels & Germany & 102,543 \\
\hline 6. & InnDependent Boutique Collection Hotels & USA & 102,185 \\
\hline 7. & Global Hotel Alliance & Switzerland & 100,000 \\
\hline 8. & Supranational Hotels & Great Britain & 85,243 \\
\hline 9. & Sceptre Hospitality Resources & USA & 81,997 \\
\hline 10. & The Leading Hotels of the World & USA & 63,387 \\
\hline
\end{tabular}

Source: www.hotelsmag.com

The use of modern technology is one of the most important factors of dynamic changes in the modern hotel industry. According to the estimated data, during 2013, more than one fifth of nights was due to online bookings. Also, over one-half of nights was reserved in direct contact of guests with the hotel, without any mediation.

Year after year the population of the upper middle class in China is growing, who, according to the research by AT Kearney, are the most active travelers. They are primarily interested in traveling by themselves, without tourist agencies, booking hotel rooms usually via the Internet (58\% of passengers) or in direct contact with hotels $(28 \%)$. This method is more complicated for hoteliers, but taking into account that this is a clientele of good payment ability who likes to travel, the interest is to attract as many tourists as possible (Goh et al., 2013).

The largest application of modern technologies is related to the younger contingent of passengers. Tourists born between 1980 and 2000 (popularly called Generation Y or Millennials) represent the most dynamic segment of the society, whose demands are hardest to follow, but are also impossible to put aside. This segment of the population still has a lot of free time ( $40 \%$ of Gen Y do not have full-time jobs), loves to travel, they are curious, globally oriented, and in 5 to 10 years will be a part of the society that spends the most on tourist trips (Global hospitality insights, 2013). Unlike previous generations, who travelled and resided in hotels, and their impressions passed on only to friends and relatives, Millennials send their impressions instantly around the world, through social networks, which can be the most effective advertising, but can also be negative advertising. Therefore, photos and websites themselves are not even nearly as important to potential guests as visitors' reviews are. Also, taught to constantly be on the move, Generation Y plans their trips quickly, so last minute deals have become part of everyday life, which may pose problems for hotel managers. Finally, hoteliers are forced to adapt to new trends, and new hotels, turned to the needs of new generations, are trying to offer what modern clientele is seeking (smaller and cheaper rooms, free Wi-Fi, etc.) (Global hospitality insights, 2013). New analyzes of leading tourism websites, indicate increased demand for hotel reservations through the Internet. According to demand of tourist products, hotel reservations are on second place, just behind the airplane tickets, and front of a rent-a-car, cruises reservations etc. (Šušić \& Đorđević, 2011). 
Also, the very structure of hotels is changing from year to year. The modern hotel industry is characterized by a higher share of small and medium size hotels (Mastura et al., 2010). One of the problems that characterizes contemporary hotel business is the number of employees in hotels. Hotel owners are trying to have fewer employees, to reduce costs and maximize their own profit, while at the same time trying to attract more visitors and fight growing competition. On the other hand, overloaded workforce eventually gives diminishing results, which negatively affects the quality of hotel business. The largest number of staff in the world, in relation to the number of rooms is in Indian hotels and is 1.6, although this ratio in four-star hotels is 1.8. The reason for such high employment levels is primarily a hotel owners wish to maximize the capacity of the hotel (Indian Hotel Industry Survey, 2011).

\section{The spatial distribution of hotel chains in the world}

The spatial development of the hotel industry has gone through four phases. The first stage was the longest, when the hotel industry was facing only the domestic market. The second stage is the beginning of the internationalization of the hotel industry, through the establishment of branches outside their own countries. Achieving success abroad leads to the third stage, when hoteliers joined other tourism and hospitality businesses, for the purpose of more complex supply. The last phase is of global character, when the whole planet is viewed as a potential market, and a hotel chain largely manages to implement the defined standards in all its facilities worldwide (Svorcan, 2008).

Factors that have led to the development of international hotel chains were of external and internal type. External factors are related to the increasing demand for hotel services on the global level, as well as the need to accelerate economic development in certain areas. Internal factors are mainly related to the market and organizational aspect of the business. The market aspect is primarily meant guaranteed service quality, while the other implied creating a new organizational structure, due to the expansion in the international market and the increase of hotel services (Radosavljević, 2008).

Modern hotel chains have a tendency towards constant expansion, the expansion including not only quantitative, but also qualitative increase, in terms of greater diversity of supply. It is therefore considered that it is not enough to make a hotel whose clientele will be, for example, business people, but it is necessary to make more hotels according to payment possibilities of these business people. In this way, all market segments are covered and each provides exactly the kind of service you expect, or can pay for. One concrete example is the "Hualuxe Hotels and Resorts", as part of IHG hotel chain, which is primarily intended for the Chinese clientele (www.ihgplc.com). IHG is the brand founded in March 2012 in order to attract guests of rapidly growing Chinese tourism market. Hualuxe hotels also offer traditional Chinese hospitality and high international hotel standards tailored to Chinese needs. To begin with, the hotels of this brand are built only in China, but there are plans to expand to all areas where there are Chinese travellers.

The expansion of modern hotel business is characterized primarily by creating new brands, within existing corporate chains, thus covering all market segments. The five largest hotel chains own 66 hotel brands, all in order to meet market needs. 
Therefore, IHG owns nine hotel brands, "Choice Hotels International," eleven brands, "Hilton Worlwide" ten, "Wyndham Hotel Group" seventeen, a "Marriott International" even nineteen hotel brands (Mašić, 2013).

The newly created brands remain attached to the name of the chain, thus advertising the type and quality of service that customers associate with the name of the hotel chain. The expansion of hotel chains in the modern world is a very dynamic phenomenon, not only manifested through the construction of new hotels, but very often through mergers, purchases, acquisitions, franchising, etc. The most dynamic period was between 1995 and 2005, when it recorded an increase in the number of hotel rooms of about $85 \%$ (Table 3.). The fastest growth in this period was achieved by economy hotels, especially "Holiday Inn Express", which over 10 years increased by more than 100,000 rooms, which accounted for $60 \%$ growth of IHG chain, to which it belongs (www.hospitalitynet. org).

Perhaps the best example of the expansion in the hotel industry is seen on the example of the IHG hotel chain. First, the British brewing company Bass bought the hotel chain "Holiday Inn", and in 1999 ceased to be engaged in the production of beer and changed the name of the hotel chain to "Six Continents". Four years later, "Inter Continental Hotels Group" (IHG) was separated from this chain, with brands such as "Holiday Inn", "Holiday Inn Express", "Inter Continental”, "Crown Plaza", "Staybridge Suites ", and through the purchase of "Candlewood Suites " reached number one in the world in 2004, where it is still today (Radosavljević, 2008).

Table 3. The largest hotel chains in the world in 2013.

\begin{tabular}{|c|l|c|c|r|}
\hline No. & \multicolumn{1}{|c|}{ Hotel chain } & Country & $\begin{array}{c}\text { No. of } \\
\text { rooms }\end{array}$ & \multicolumn{1}{c|}{$\begin{array}{c}\text { No. of } \\
\text { hotels }\end{array}$} \\
\hline 1. & IHG (InterContinental Hotels Group) & Great Britan & 679,050 & 4,653 \\
\hline 2. & Hilton Worldwide & USA & 678,630 & 4,115 \\
\hline 3. & Marriott International & USA & 675,623 & 3,916 \\
\hline 4. & Wyndham Hotel Group & USA & 645,423 & 7,485 \\
\hline 5. & Choice Hotels International & USA & 506,058 & 6,340 \\
\hline 6. & Accor & France & 461,719 & 3,576 \\
\hline 7. & Starwood Hotels \& Resorts Worldwide & USA & 346,819 & 1,175 \\
\hline 8. & Best Western International & USA & 317,838 & 4,097 \\
\hline 9. & Home Inns \& Hotels Management & China & 262,321 & 2,241 \\
\hline 10. & $\begin{array}{l}\text { Shanghai Jin Jiang International Hotel } \\
\text { Group Co. }\end{array}$ & China & 235,461 & 1,566 \\
\hline
\end{tabular}

Source: www.hotelsmag.com

Although the growth of hotel industry is constant and powerful, it is not the result of large investments in building new facilities, but is primarily based on the franchise and management agreements. The largest funds are invested into strengthening and renovating the existing facilities, as well as into positioning hotel brands in the international market. 
Table 4. The most successful hotel chains according to franchise sale in 2013 .

\begin{tabular}{|c|l|c|r|}
\hline No. & \multicolumn{1}{|c|}{ Hotel chain } & Country & $\begin{array}{c}\text { No. of sold } \\
\text { franchise }\end{array}$ \\
\hline 1. & Wyndham Hotel Group & USA & 7,425 \\
\hline 2. & Choice Hotels International & USA & 6,340 \\
\hline 3. & IHG & Great Britain & 3,955 \\
\hline 4. & Hilton Worldwide & USA & 3,420 \\
\hline 5. & Marriott International & USA & 2,672 \\
\hline 6. & Magnuson Hotels & USA & 1,865 \\
\hline 7. & Accor & France & 1,402 \\
\hline 8. & Home Inns \& Hotels Management & China & 1,365 \\
\hline 9. & GreenTree Inns Hotel Management Group & China & 1,171 \\
\hline 10. & Vantage Hospitality Group & USA & 1,102 \\
\hline
\end{tabular}

Source: www.hotelsmag.com

Hotel franchising is becoming more and more popular form of expansion of hotel chains, especially when it comes to big and still insufficiently conquered markets, such as India and China. Franchising in the hospitality industry began in the 1960s, with the expansion of the hotel chain "Holiday Inn", and later other hotel brands (Table 4.). The hotel industry of China is the fastest growing industry in the world. Of 137 hotels in 1978 (Xiao et al., 2008), the number of hotels increased to 18,437 in 2013 (www.statista.com).

Table 5. The largest hotel chains in Europe in 2014.

\begin{tabular}{|c|l|c|r|}
\hline No. & \multicolumn{1}{|c|}{ Hotel chain } & Country & No. of rooms \\
\hline 1. & Accor & France & 262,634 \\
\hline 2. & Best Western & USA & 91,739 \\
\hline 3. & IHG & Great Britain & 88,209 \\
\hline 4. & Groupe du Louvre & France & 68,294 \\
\hline 5. & Whitbread & Great Britain & 53,313 \\
\hline 6. & Carlson Rezidor & USA & 52,091 \\
\hline 7. & Hilton Worldwide & USA & 49,758 \\
\hline 8. & Melia Hotels International & Spain & 49,464 \\
\hline 9. & NH Hoteles & Spain & 49,424 \\
\hline 10. & Marriott International & USA & 46,381 \\
\hline
\end{tabular}

Source: www.hospitality-on.com

Although the hotel chains of the United States remain the largest, their role decreases year after year, whereas the British, Spanish, and in the last few years Chinese hotel chains continue to grow. Once powerful hotel chains in Germany and France have lost their supremacy, as well as the Japanese, which are turned towards the domestic market (Table 5.).

Until 2012, among the ten largest hotel chains, there weren't any from the Asian continent. However, starting from that year, Chinese hotel chains "Shanghai Jin Jiang International Hotels" and "Home Inns \& Hotels Management", reached the ninth and tenth position, which continued to strengthen in the coming period. Changes in the global 
hotel business are also visible on the basis of the share of hotel chains in the world's total capacity (number of rooms), at the level of continents (according to the countries of origin of hotel chains). Thus, North American corporations recorded a decline in participation from $73.15 \%$ (1997) to 58.21\% (2012), while European corporations grew by $5.69 \%$ and Asian by $9.11 \%$ (Mašić, 2013). This phenomenon talks about the opening of new markets and the imminent growth of the hotel industry.

By far the fastest growth of hotel industry is in China. This is an industry that is estimated at about 44 billion dollars, with 2.5 million hotel rooms. Opinions are divided on whether the hotel industry in China will continue its advances. According to some authors, China has no need for further increasing the number of rooms, at least not at the present pace. On the other hand, the number of hotel rooms per 1,000 inhabitants is only 4, compared to the UK with 10 and the USA with 20 rooms per 1,000 inhabitants. These data suggest that the Chinese hotel industry is likely to continue to grow and is expected to increase its capital value by $\$ 100$ billion, and the number of rooms to 6.3 million. If the forecasts come true, the number of rooms per 1,000 inhabitants will be doubled (Goh et al., 2013).

Another curiosity is related to the hotel business in China. In fact, unlike other countries, where hotels are mostly privately owned, in China, according to data from 2004 , over $53 \%$ of the total number of hotel rooms are owned by the state (Xiao et al., 2008).

The growth of the hotel industry has been permanent in the last two decades. Data show that from 1997 to 2012, the 300 largest corporate chains in the world recorded an average growth rate of $4.14 \%$ (Table 6.) (Mašić, 2013).

Table 6. The growth of the largest hotel chains in the period $1997-2012$.

\begin{tabular}{|c|c|c|c|c|}
\hline Hotel chain & $\begin{array}{c}\text { No. of rooms } \\
\text { in 1997 }\end{array}$ & $\begin{array}{c}\text { No. of rooms } \\
\text { in 2012 }\end{array}$ & $\begin{array}{c}\text { Absolute } \\
\text { growth }\end{array}$ & $\begin{array}{c}\text { Relative } \\
\text { growth }\end{array}$ \\
\hline $\begin{array}{c}\text { IntecontinentalHotels } \\
\text { Group }\end{array}$ & 465.643 & 675.982 & 210.339 & $45.2 \%$ \\
\hline Marriott International & 289.357 & 660.394 & 371.037 & $128.2 \%$ \\
\hline Hilton Worldwide & 155.943 & 652.957 & 497.014 & $318.7 \%$ \\
\hline Wyndham HotelGroup & 499.056 & 627.437 & 128.381 & $25.7 \%$ \\
\hline Choice HotelsInternational & 292.289 & 538.222 & 245.933 & $84.1 \%$ \\
\hline
\end{tabular}

Source: Mašić, 2013.

The future spatial development of the hospitality industry is difficult to follow, but some directions of development can be guessed. One of the important parameters is the GDP growth, and, on that basis, it can be assumed which countries of the world are seen as potential markets by the creators of the hotel business. Three countries stand out as the most promising areas for the development of the hotel industry: China, India and Russia (Developments and challenges in the hospitality and tourism sector, 2010). In the area of all three countries, the influence of global hotel chains, until 10 years ago, was insignificant. During the last decade, there have been significant changes in the structure, organization and spatial distribution of global hotel chains in these countries. Permanent GDP growth, characterizing these countries, places them in the first position in the 
world, China, in the second, Russia the eighth and India in the tenth place (www.imf. org). We should not neglect Brazil, as the seventh country in the world according to GDP growth, which, although having a long tradition of big hotel chains in the world, still has significant potential in terms of expanding the hotel business. It should also be noted that in the above-mentioned countries, there is a rapidly increasing percentage of the rich middle class, who travel a lot. This trend is reflected in the fact that the largest consumers in international tourism in 2013 were the Chinese with 128.6 billion dollars and annual consumption growth of close to $24 \%$. Faster growth was recorded only by the residents of Russia (28.9\%), which ranks fourth in the world, with the consumption of 53.5 billion dollars. Brazil occupies the tenth position in the international tourism expenditure with 25.1 billion and the increase of $12.9 \%$. Other countries, which are among the top ten, the USA, Germany, UK, France, Canada and Australia, recorded growth in the range from $2 \%$ to $8 \%$, with the exception of Italy, which recorded a decrease in consumption (Tourism Highlights, 2014).

\section{Conclusion}

Rapid changes and globalization of the world tourism market dictate trends that compel modern hotel industry to constantly adapt in order to maintain and take strategic positions in relation to their competition. Technology plays a major role in the development of hotel products and services offered to guests.

Global economic development and availability of all parts of the globe provide incentives for mass travel, which increases competition in the hotel business, as tourists can now use the services in any part of the world for the same price. Therefore, hotel management is forced to constantly meet the demands of consumers, predict their future needs, train and improve the supply and quality of services in order to attract and retain increasingly demanding customers and survive in the modern conditions of competition.

One of the most important characteristics of modern hotel business is related to business integration and connectivity, through the creation of powerful hotel chains and through the expansion over a large number of countries. From the very beginning of hotel chains, their expansion is evident, and according to current information, the growth of their activities will continue in the future.

Trends show that the independent hotel business is a too risky way of doing business, with data showing that an increasing number of individual hotels, one way or another, associate with a hotel chain, as the competition on the world market is extremely strong.

Therefore, it can be concluded that the modern hotel industry is going in the direction of further concentration of capital, greater expansion on the global market, especially in those areas that have a huge economic and demographic potential, such as China, India and Brazil. 


\section{References}

Bardi, J. A. (2011). Hotel Front Office Management, $5^{\text {th }}$ edition, The Pennsylvania State University, John Wiley \& Sons, Inc.

Čačić K. (1998), Poslovanje preduzeća u turizmu, Ekonomski fakutlet, Beograd Čačić, K. (2010). Poslovanje hotelskih preduzeća, Univerzitet Singidunum, Beograd

Developments and challenges in the hospitality and tourism sector (2010). Issues paper for discussion at the Global Dialogue Forum for the Hotels, Catering, Tourism Sector Geneva, International Labour Organization, from http://www.ilo. org/wcmsp5/groups/public/@ed_norm/@relconf/documents/meetingdocument/ wcms_166938.pdf, (19.02.2015)

Global hospitality insights, Top thoughts for 2014. (2013), EYGM Limited, from http://www.ey.com/Publication/vwLUAssets/EY_-_Global_hospitality_ insights_2014/\$ FILE/EY-Global-hospitality-insights-2014.pdf (21. 02. 2015.)

Goh, M. F., Gan, C. W. \& Kim, D. (2013). China's hospitality industry - Rooms for growth, A.T. Kearney, from www.atkearney.com/transportation/ideas-insights/ featured-article/-/asset_publisher/4rTTGHNzeaaK/content/chinas-hospitalityindustry-rooms-for-growth/10192 (12.02.2015)

http://www.statista.com (17. 02. 2015.)

http://www.hotelsmag.com/h1507_Special_Report.pdf (20.02. 2015.)

http://www.ihgplc.com/index.asp?pageid=856 (20. 02. 2015.)

http://www.hospitalitynet.org (12.02. 2015.)

http://www.hospitality-on.com (18. 02. 2015.)

http://www.imf.org (18. 02. 2015.)

http://www.portmanusa.com/project.php?projectid=5620 (21. 02. 2015.)

Indian Hotel Industry Survey 2010-2011 (2011). Federation of Hotel \& Restaurant Associations of India, from http://www.hvs.com/Content/3216.pdf (14. 02. 2015.)

Mastura, J., Siti, A. M. \& Siti Z. S. (2010), Entrepreneurial Characteristics of Small and Medium Hotel Owner-Managers, World Applied Sciences Journal 10., Special Issue of Tourism \& Hospitality, IDOSI Publications (54-62), from http:// citeseerx.ist.psu.edu/ viewdoc/download?doi=10.1.1.390.5697\&rep=rep1\&type $=$ pdf (19.02. 2015.)

Mašić, S. (2013). Korporativni hotelski lanci na savremenom hotelijerskom tržištu, Hotelska kuća 2013, IX Međunarodni naučno-stručni simpozijum, Poslovno udruženje hotelsko-ugostiteljske privrede Srbije, Zlatibor, (94-102)

Radosavljević, G. (2008). Hotelski lanci u procesu globalizacije, Ekonomski horizonti 10, br. 1-2, Ekonomski fakultet, Kragujevac, (33-43)

Svorcan, N. (2008). Globalni lanci hotelske industrije, Visoka hotelijerska škola strukovnih studija, Beograd 
Šušić, V., Đorđević, D. Ž. (2011). Uloga ICT-a u unapređenju poslovanja turističkih agencija, Ekonomske teme, br. 4., Ekonomski fakultet, Niš (681-694)

Tourism Highlights 2014 Edition (2014). UNWTO, from http://www.e-unwto.org/ doi/ pdf/10.18111/9789284416226, (18. 02. 2015)

Xiao, Q., O’Neill, J. W. \& Wang, H. (2008). International hotel development: A study of potential franchisees in China, International Journal of Hospitality Management 27, Elsevier (325-336) 